\title{
The power of the projected self: a case study in self artistry
}

\section{N Rapport}

J Med Ethics; Medical Humanities 2005;31:60-66. doi: 10.1136/jmh.2004.000204

The "projected self" is an individual engaged in a life project. The power that enables an individual to formulate, to embark on, and to effect a life project is of an "existential", embodied kind: something fuelled metabolically within the body of the individual, and conceived of by way of his or her ongoing, individual acts of interpretation. In this article the life of the English artist Stanley Spencer is looked to as a case study through which to flesh out and apply the above conceptual terms and their argument. To what extent can there be said to be a relationship between the "work of art" that Spencer created in and as his life, and his influence over those forces and those others that might otherwise have claimed a hold over his life? Spencer's construction of a beautiful, involved, and extensive worldview, the article argues, does translate into him exercising a conscious control over the course of his life and enjoying a wellbeing of identity.

Correspondence to:

Professor Nigel Rapport, Centre for Cosmopolitan Studies, Department of Sociology and Anthropology, Concordia University of Montreal, 1455 de Maisonneuve Blvd West, Montreal, Quebec H3G 1M8, Canada; nigel.rapport@ concordia.ca

Received 4 May 2004 Accepted for publication 27 November 2004
$\mathrm{T}$ his essay concerns power, but not power as conventionally understood and represented in social science. Rather than an appreciation of the structural power of what is institutional, collective, impersonal, and not individual to create and/or curb what is individual, this is an essay concerning the existential power of individuals to create and lead their own lives.

More precisely, the issue that the article sets out to examine is the relationship between consciousness and control: between consciousness of an idea of self in the world, and control over one's individual life in the world. In so far as persons lead their lives in terms of objectives and criteria of evaluation that are of their own formulation and deployment, do they thus put themselves in positions to ameliorate or even escape the influence of social conditions, factors, and forces beyond themselves? If we treat their lives as their own "life projects", their actions, can be seen to be answerable, largely or wholly, to their own worldviews and the conscious fulfilment of these, and not to ideologies, social structures, and the structures of the unconscious and embodiment, the so called prison houses of language and history. Self consciousness-the exercise of a certain "self intensity", projecting one's self along a determined life courseequates with a freedom from the conditions of external circumstance beyond the self.

I explore this issue by bringing together social, scientific, and aesthetic analysis ${ }^{1}$ in an examination of the life and work of one particular individual: the English painter Stanley Spencer
(1891-1959). In constructing an artistic oeuvre of great originality and vision, Stanley Spencer, I shall argue, exhibited a large degree of single mindedness in his life-singlemindedly focused on a certain life project-and thereby achieved a remarkable order and control in and over the course of his life and the things to which he consciously attended while living it. He succeeded in placing himself in the middle of an abundantly meaningful and intense life narrative; this did not entail subordinating his life to his art so much as intending to live his life as an artwork, as a manifestation of his artistic vision.

Here is how Stanley Spencer is introduced by his first biographer, Maurice Collis²:

He stands a giant (though physically he was a very small man) who was never deflected from his main concern, which was to express himself. His story is bound up with three women in particular [Hilda Carline, Patricia Preece and Daphne Charlton], and also a fourth [Charlotte Murray]. He was influenced by them for a time, but remained unchanged in essentials. They people his art from 1927 till his death and are a recurring subject of his writings. But he was a recluse at heart, a paradox of which his [posthumous] papers leave no doubt.

The question I pose is whether Spencer's construction of a beautiful, involved, and extensive worldview translates into him being able to be described as having control over his life. What is the relationship between the edifice, the narrative, the "work of art" that Spencer created in and as his life, and his influence over those forces and those others that might otherwise claim a hold over his life? While I do not directly address the question of happiness, of whether his pursuit of a life project was responsible for Stanley Spencer (or those around him) being happy or unhappy, an issue of wellbeing does become relevant. I explore the extent to which Spencer's self intensity and self artistry gave rise to a kind of fitness or strength: of character, of identity. Consciousness of an idea of self in the world, and living to project that idea in action, may be instrumental in effecting a kind of ontological wellbeing.

Before we meet Spencer in more detail, I introduce some concepts and terms that aid the analysis.

\section{"DISPLACEMENT"}

My point of analytical departure is the concept of displacement. Etymologically, the word derives from Old French: a negation of place. "To 
displace", is to shift or remove or oust from an erstwhile proper, usual, official, or dignified position or place; whereas "displacement" is a measure of difference between an initial and a subsequent position and embodies movement (Shorter Oxford English Dictionary). Hence, a "displaced person" is a refugee or stateless person, someone removed from his country as a prisoner or slave (Chambers Twentieth Century Dictionary).

However, a negation of place, an overcoming of place, might also be conceived of as a positive move; and displacement as a conscious and creative act by which an individual shifts and removes and ousts himself or herself (and perhaps others) as a route to growth. Displacement affords a distance, and a measurement of difference, between an initial identity and a subsequent one. Becoming a refugee or exile from a social milieu or relationship or lifeworld, becoming someone else, the individual assures himself or herself of a vantage point from which to look sideways at their life and consciously create anew. "Power", as the early American "transcendentalist" philosopher, Ralph Waldo Emerson, proposed, "resides in the moment of transition from a past to a new state, in the shooting of the gulf, the darting to an aim"; while it "ceases in the instant of repose". ${ }^{3}$

In displacement lies a source of personal, "existential" power to be and to do.

I am encouraged in this view by the thoughts of the contemporary Emerson scholar, George Kateb. To stay in one place (intellectually or emotionally), Kateb asserts, ${ }^{4}$ is to put at risk one's capacity for experience and creativity. Indeed, even to come to know oneself it is necessary to some degree to become alienated or estranged, and thus to see oneself as from a distance; one explores and becomes oneself. Displacement thus encourages what Emerson called "self reliance". Periodically examining oneself and thinking through one's own thoughts, one is not the self same person as the non-displaced one. Moreover, the self one becomes is not constructed merely out of the givens of social milieux and historical circumstance. Displacement has shifted, in an idiosyncratic way, the context of that life: the criteria of judgment upon which it might rely. Displacement gives rise to a habit of self judgment and self authentication, the life becoming answerable to questions posed of it by its individual owner, not (or not only) its consociates in its social milieu. The life becomes a self narrated one.

Kateb calls such a process one of self recovery: it is an arriving "home", coming to live "in one's own place". ${ }^{5}$ It is the case, moreover, that the displaced and self examined person is better able, possibly, to withstand (deny, escape) the constructions made of him or her by others, and the categorising. A sense of the course, the trajectory, of one's own life, knowing where one has moved from and could be moving towards, affords one distance from the placements of others.

\section{“EXISTENTIAL POWER" AND “'IN ORDER TO' MOTIVES"}

Emerson's statement concerning the power of movement and becoming, which I quoted above, ends as follows: "This one fact the world hates; that the soul becomes; for that forever degrades the past, turns all riches to poverty, all reputation to a shame". ${ }^{3}$ On the question of displacement, certainly, analysts from Marx and Durkheim, through Freud to Heidegger and Homi Bhabha, would degrade the notion by identifying it with alienation and anomie, homelessness and exile: with individual powerlessness and lack or loss of control. Analysts fight shy of welcoming the radical newness of the displaced "soul", the unpredictability and nonclassifiability to which its idiosyncratic "becoming" might be party.
This also accords with a more general social scientific tendency to regard the individual actor as "put upon" rather than "putting on", not so much "self motivated" as "socially driven". ${ }^{6}$ Identity becomes wholly a matter of social relations, of what particular social settings cause, construct, classify, elicit. Phenomena such as displacement then become attributes of social milieux, of their conditions and relations, rather than aspects of life that an individual person might be consciously and creatively responsible for effecting. In Alfred Schuetz's designation, ${ }^{7}$ causal or "because" motives, predominate in conventional analytical treatments of behaviour in social milieux, whereas intentional or "in order to" motives rarely figure beyond the realm of pathology. In the rush to deconstruct the "political power" of techniques of influence and oppression, a recognition of the "existential power" to act and constitute identity is lost. ${ }^{8}$ That is, a focus on "institutional processes of governance" eschews a broader conceptualisation of "the power to do, the capacity to achieve things or projects".

Questions, such as how individuals cope with life or find meaning in the face of suffering or change, become over determined by questions of social domination, hierarchy, and control.

I would wish to turn this around, however, and, as with the according of a positive characterisation to displacement (regarded as a source of personal power), locate forces of behavioural determination, of the instituting of meaningful worlds, in the individual as such. I would go so far as to say that there are only "in order to" motives; "because motives" are what we formulate out of bad faith in order to claim that something or someone other than ourselves is responsible for what we feel, think, say, or intend. "Bad faith" is a Sartrean notion, ${ }^{10}$ and existentialism is the moral philosophy that has most determinedly, perhaps, argued the case I would substantiate in this essay. ${ }^{11}$ Individual consciousness creates the meaning of the world and the objects in it, the existentialist claims, rather than that consciousness being the internal manifestation of another, extraneous forcesuch as Society, the Unconscious, or God. We have a freedom to shape our own individual destinies. Awareness of this, however, can cause anguish; we are fearful and unconfident concerning the consequences of our action or our inaction, and our responsibility concerning the choices and decisions of our lives. Hence our flight into "inauthentic living" and lies. Confronting our authentic selves in their aloneness is frightening and so we shirk the responsibility, in bad faith, and say our choices, our lives, are determined by our religious doctrines, our personal pasts, our cultural traditions. For our freedom in a fluxional universe we substitute orderly systems, theoretical schemas, and determinate structures. This is both a trick that we play on ourselves and on others, and which others would play on us; it is a means of control. Impersonal and extraneous "because" motives serve the interests of those who would exercise power over others.

It is the case, however, that (to adapt a phrasing of Alfred Whitehead's) such impersonal idioms usher in a "fallacy of misplaced concreteness" concerning the order of the world and its source: the ideological and merely conventional are taken and mistaken for the real.

"Genius", Nietzsche wanted to prescribe as something to be acquired, something one grew into. ${ }^{12}$ My emphasis here, too, is on the developmental aspects of self intensity or single mindedness: they are matters of positive feedback. The practice of living "in order to", of framing one's life in terms of a life project, bestows certain qualities of character on its exponents. Indeed, having and maintaining a life projectexpecting to see projects of displacement, change, and growth through to completion-may be found to be the most important element in the life project's effectiveness. As 


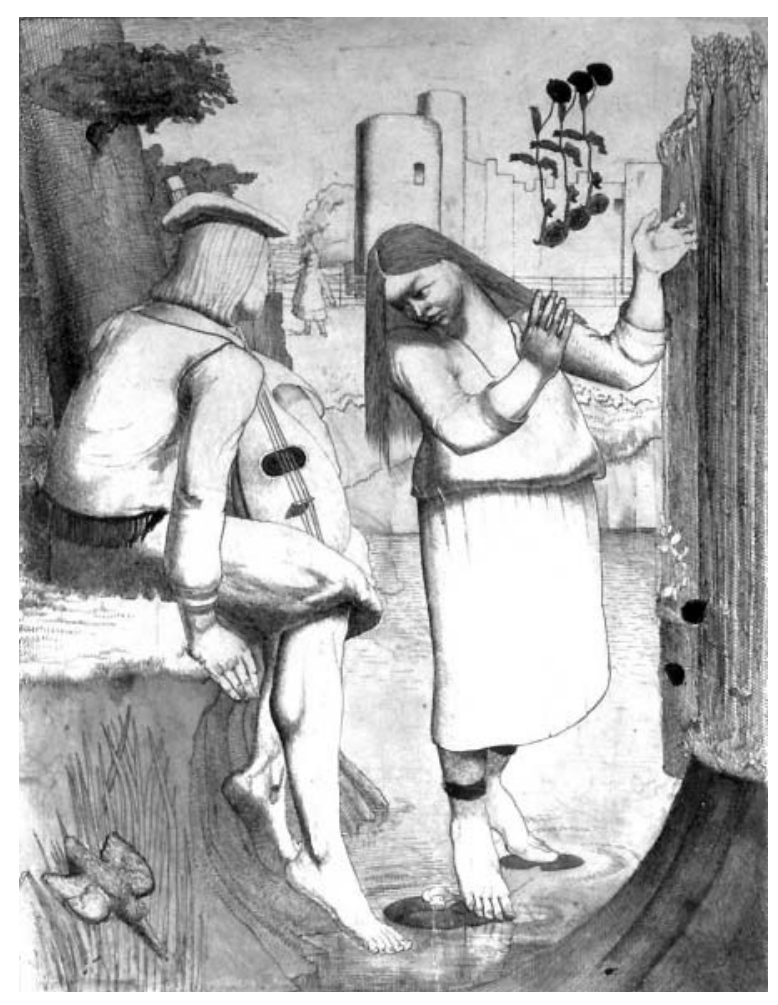

Figure 1 Stanley Spencer, 'The Fairy on the Waterlily Leaf' 1910. Copyright: Estate of Stanley Spencer 2005. All rights reserved (Dacs/ Sodart). Source: Stanley Spencer Gallery, Cookham, Berkshire, UK/ Bridgeman Art Gallery.

in a dialectic, the individual practising of a life project may be responsible for the continuing disposition to keep on practising: practice itself may be the key to the power accrued to control the trajectory of the life imbued by a life project.

\section{STANLEY SPENCER AND THE METAPHYSICS OF LOVE}

Let me illuminate this thesis by turning the attention of the essay to one life in particular, that of Stanley Spencer: to his imaginative, painted displacements, and their effects on his life. I begin with two quotations:

Spencer: "I have always looked forward to seeing what I could fish out of myself. I am a treasure island seeker and the island is myself" (Collis, ${ }^{2} p$ 203).

Hilda Spencer: "Being with Stanley is like being with a holy person, one who perceives. (...) he is the thing so many strive for and he has only to be. (...) Stanley's home seems to be the whole world"'. (Pople, ${ }^{13}$ p 463).

In his biography of Stanley Spencer, Kenneth Pople ${ }^{13}$ offers an interpretation of Spencer's early pen and ink sketch, The Fairy on the Waterlily Leaf.

The sketch was drawn in 1910 when Spencer was nineteen, at the request of a Miss White, to illustrate a fairy story she had written. She was not pleased with the result, however, and rejected it. Spencer was puzzled by the rejection and disappointed. Nine years later he again gave it as a gift, this time to his friend Ruth Lowy and her betrothed, Victor Gollancz (the publisher), and again was asked what it meant. He replied that it was a fairy on a water lily leaf but that beyond that he did not honestly know what the picture was all about. "I was loving something desperately", Spencer later wrote of this time, "but what this was I had not the least idea". What this something was, Pople suggests, ${ }^{13}$ was Spencer's dawning awareness of the miracle of love as such: Spencer's "metaphysic of love" as it was to become. Drawn from deep personal feelings as yet unclarified, it is this that the sketch sets out to honour.

Pople elaborates as follows: ${ }^{13}$ Spencer's fairy, no elfin, is a sturdy girl seemingly impossibly posed on two water lily leaves above a pond. She is being courted by a prince in Renaissance dress (in the form of a certain youth, Edmunds, a male model from Spencer's life class at the Slade School of Art, London). The fairy figure is a representation of the village girl Dorothy Wooster, with whom Spencer had been a school pupil at Cookham-on-Thames. In order to imagine a prince's love for a fairy - the theme of Miss White's original story-Spencer has assembled images from his own experience; in this way he sought to reproduce the emotion of the theme. He draws Dorothy, therefore, beautiful and impossibly buoyant (physically) because he has loved her (metaphysically): the reality of the imagery becomes subservient to the emotion he feels for what is imaged. As for the water, he chose a little sandy beach by the bank of the Thames that he knew from happily playing there as a boy. Finally, he adds scale to the central scenario by diminishing Dorothy's size relative to a row of wheat stalks on her right, and he adds perspective by way of three flowers or marsh plants, which he draws in the top left hand corner. From one perspective the plants seem to have been thrown up into the air by a juggling Dorothy (one of Spencer's elder brothers became a professional juggler). But from another perspective, the marsh plants suggest that Spencer wishes us, like the prince, to be looking down on the scene as from above: to see the artist as having made the vertical height of the sketch into a horizontal expanse of clear water. We and the prince are looking through the water of the pond at the fairy as through a plate glass window.

The fairy's world is enchanting and lovable but also enchanted and intangible-as enchanted perhaps as the world Spencer hears through music (thus the crotchet like shape of the plants), and as intangible as his (dawning) world of love still is for him. The fairy is an emanation of that world, but she must return there when the music stops; the prince cannot follow (any more than Spencer could follow the village girls into their world or find his visions in their disappointing conversation).

Nevertheless, in the picture there is the hint of love transcending the boundaries between worlds and their displacements: the physical and the spiritual, the everyday and the heavenly. Also in the picture are the elements of a visionary world, which brings together Spencer's local experience and his dreams and hopes of redemption through love, themes that were significantly to characterise his mature art. Manifesting a "metaphysic of love" was, indeed, to become his life project.

\section{AN ARTFUL AUTOBIOGRAPHY}

In 1938 some friends (including Victor Gollancz) tried to encourage Spencer to write his autobiography; it would help him explain himself to a public becoming distanced by (what John Berger would dub) the intrinsic "oddness" of his paintings' personal iconography. ${ }^{14}$ At first Spencer was quite taken with the idea, for in writing an autobiography he would be seeing his life as a whole, and the "constant something in myself that I consider to be the essential me that I like". He would compose not a linear chronological narrative but, as it were, a stroll through his life, with digressions and pauses as the mood took him, and in 
different genres and styles; chronological development was less important to account for than a sentimental one.

Eventually, however, Spencer decided against it; if people would not understand his paintings, then why should they understand his explanations? Nonetheless, he did begin to write in private. For the next 21 years he composed diaries, journals, random jottings, extensive essays, and unsent letters. ${ }^{15}$ He wrote obsessively and kept every scrap: entreaties, memories, fantasies, philosophies, love makings; about and to his paintings, wives, and family, friends, and himself. Collected in trunks, he would dip into the storehouse, the treasure chest, to reread, reannotate, repaginate, and rearrange; the writing, he explained, meant he could sort out his thoughts. (Archives are today housed at The Stanley Spencer Gallery, Cookham, and The Tate, London.) In seeking a fuller appreciation of Spencer's art, then, the displacements he achieved through it, and the place of both the art and the displacements in the conscious control he exercised over his life, it is apposite to borrow a selection of Spencer's words as accompaniment and counterpoint.

Spencer's art, I want to argue, was something he used both to prescribe a general metaphysic for earthly life and to describe-reflect, correct and redeem-his own life in particular. It amounted to a life project through which he succeeded in living on his own terms.

Spencer surprised people because, when asked if he believed in God, he never knew what to say. Certainly he cherished no notions of an intimate figure, and he was appalled by those who made religion an excuse for dividing believers from non-believers, members from non-members, and instituting a certain discipline on the world and its beings.

\section{It is for me to go where the spirit moves me, and not to attempt to ally it to some known and specified religion (cited in Pople, ${ }^{13}$ p 275).}

Nevertheless, a good place to start the story of Spencer's art is with his Wesleyan Methodist upbringing. This, together with Gladstonean liberalism, permeated his childhood. Here was a value placed on non-monetary things and a faith in perfect universal love, mediated by a one to one relationship with God that was attainable on earth. All came together in the imagery of the Bible and services in Cookham Wesleyan chapel: homely, gentle, secure, comfortable, and productive. It gave onto a coherent world order whereby, to an imaginative boy and youth, Cookham village seemed to manifest a "sacred presence". Here, the natural and the supernatural co-mingled and visions might be taken for granted. If the family home was the major part of the terrestrial world, then maids talking to themselves in the attic were likely communing with angels: the biblical shepherds watched their flocks on the field below Cliveden Woods, and Cookham churchyard was the path to Eden. The eternal stories of the Bible Spencer located in his own parochial childhood environment, translating their drama and fiction into the reality of his own familiar, everyday experiences.

\section{I became aware that everywhere was full of special meaning and this made everything holy (...). I saw many burning bushes in Cookham. I observed this sacred quality in most unexpected quarters. \\ [Cookham]: holy suburb of heaven (cited in Glew, ${ }^{15} \mathrm{pp}$ 164-5).}

Cookham simultaneously inspired Spencer and grounded him: allowed him to see universal truths and provided him with contact and bearings on the here and now. The sense of the village representing an earthly paradise stayed with him throughout his early adulthood. The experience of London and the Slade (then under the influence of Continental art movements such as PostImpressionism, Cubism, Vorticism, and Expressionism) only made him more sure: everything in Cookham was cosily innocent and of the morning. Sitting in the family pew at church one morning in 1915, and hearing the activities of the village and the river going on outside, and again having the sense of the holiness, the sanctity, of the whole-church and village, "sacred" and "profane"Spencer explains how he had the idea of taking his "in church" feeling "out of church" in his art, transferring an act of worship to seemingly secular rituals, people, and places.

The thing which interests me and always has done is the way that ordinary experiences or happenings in life are continually developing and bringing to light all sorts of artistic discoveries (cited in Robinson, ${ }^{16}$ p 41)

It was an idea (a unity and a stillness) that would initially be disrupted by the war, but to which he would return thereafter with redoubled inspiration and zeal. To an extent, his experiences in the first world war provided a decisive rupture to Spencer's life and the innocence of his vision. Thereafter, "Cookham" represented a rapturous golden age he must now be intent on recapturing: intervening experiences had to be redeemed.

As a medical orderly and latterly a soldier, he had succeeded in mentally escaping a detestable deindividuation and regimentation, finding a personal spirituality in menial tasks and everyday routines (courtesy of Augustine's Confessions), but it was not until he began painting again that a full catharsis was achievable.

The first place an artist should find himself is in prison. The moment he realizes he is a prisoner, he is an artist, and the moment he is an artist, he starts to free himself. [Painting] redeemed my experience from what it was; namely something alien to me. By this means I recover my lost self (cited in Glew, ${ }^{15}$ p 120).

Marrying his thoughts and feelings to people, places, and events around the village - the divinity of their occupations, the ritual of their daily activities-was to create something holy.

The war was not, however, the only disruption of a major, even tragic, kind in Spencer's life. His discovery of sex; his marriage to fellow artist Hilda Carline (1925); his polygamous desire for Patricia Preece; his divorce from Hilda (1937); his estrangement and divorce from Patricia; his feelings of terrible loss over Hilda; his persecution by a censorious public; his relative poverty, and peripatetic existence (moving between houses at Cookham, Bourne End, Durweston, Steep, Petersfield, Hampstead, Poole, Burghclere, St Ives, Swiss Cottage, Leonard Stanley, Port Glasgow and Epsom)-all of these precipitated crises of consciousness. In each instance, however, it was in his artworld (his writing as well as his painting) that Spencer successfully found equilibrium: a continuity and coherence to the narrative of his life, redemption for what had passed, joy in what was now, and hope for what was to come. Above all, art provided a fulfilment that was missing in life; art created order out of the disruption, the chaos, of life.

I am aware that all sorts of parts of me are lying about waiting to join me. It is the way I complete and fulfil myself (cited in Bell, ${ }^{14} \mathrm{p}$ 14). 
There is, however, more. To this personally cathartic displacement he will marry a supernatural (initially Wesleyan but increasingly pantheistic, even Buddhist) iconography. Heaven and earth are innocently unified, as are races, nations and creeds, men and women, humans and animals, self and other; secular and numinous, bodily and spiritual desire, innocence and experience. Although Spencer rejected the liturgical literalness of canonical religion, he still employed the paradigm of Christianity as a resource because it offered a sense and interpretation (one among many possible ones) of the disparate mysteries of the world-and the wonder of experiencing it. What Spencer asked of his audience was not necessarily empathy, nor even sympathy, with his personal vision and representation of this universal consciousness, but an acknowledgement that existence is something whose awesomeness they sensed too. Ultimately, Spencer's vision was also a parochial one: a cult of the sacred self, which focused not on Jerusalem, or Paris, or Rome but on the provincial world of Cookham. If the Christian Bible was an allegory of a great truth about the world, then Cookham was too, if its "pages" were read with the vision that Spencer's art would provide; happenings in Cookham represented a pageant of revelations equivalent to those in the Bible, and Spencer's destiny was to relate the wonder and awe of the one to the other.

It was as if people and events in Cookham were communicants of a church of which he was the priest. Here was a deeper level of human and spiritual consciousness, which brought about a new, true state of being, a more magnificent and beautiful way of life, which he saw "out of doors" in Cookham. Like a mediaeval artist/craftsman/ villager, Spencer would endeavour to capture the essence of these manifestations of ordinary local life for local people. For in the same way that Cookham was imbued with a divine truth, so too, was he, Spencer. The apparent unchangingness of Cookham revealed an everlasting, mysterious rhythm: the recreation of life from death; the emergence of form from meaningless chaos. Likewise, from the random pieces that the world of the senses continually emptied into his brain, he would create art and reveal the wonder of the identity of each thing on earth, and hopefully transmit something of the ecstasy that this led him to feel.

[A mass of] inward, surging meaning, a kind of joy, that I longed to get closer to and understand and in some way fulfil (Spencer, ${ }^{17}$ p 80).

His vision afforded Spencer a form of transcendence.

Finally, through his art, Spencer would not only celebrate his existence (its conflicts, disorders, and discords becoming joys) but also redeem it. His paintings were a miraculous means by which Spencer would get himself to where all was holy, personal, and at peace: to where he was at home in the universe. Like Christ's, his real triumph would lie not in a material kingdom but in a spiritual overcoming; like Christ (despite the agonies of the inevitable and perpetual confusions and frustrations of existence) he would find both meaning and liberation in his creativity, by finding himself in communion with God and Nature.

\section{[T]o produce something which would make me walk with God. \\ I loved it all because it was all God and me, all the time (cited in Bell, ${ }^{14}$ p 29).}

Spencer's vision amounted to a continuous procession in his mind: an unrolling pageant of material/spiritual sensations and expressions. It could overwhelm him but it also provided a magisterial transcendence, and he dedicated his life and art to its reproduction. His personal vision was ultimately individual and private.

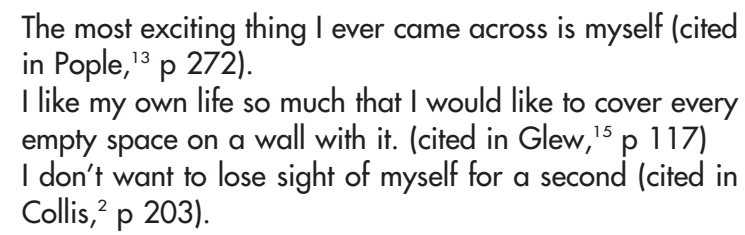

\section{ARTWORK: COMPENSATION OR FULFILMENT}

Resurrection was a favoured subject of Spencer's and throughout his life he painted a number of works with this word in the title, set in places to which he felt he belonged, and which he loved; through the painting he was able to come to know the place even better, and also to express his love better. Thoughts of resurrection were never far from Spencer's mind, it seems, and the "last day", when resurrection would take place, became an all encompassing theme, an umbrella concept for his artistic vision as a whole. What Spencer conceived of in a "resurrection of the dead" was not necessarily physical so much as a becoming aware of the real meaning of life, and becoming alive to its enormous possibilities. Resurrections are displacements: awakenings to a state of realisation of the potentialities of heaven on earth which sex and love, joy and oneness (as against cruelty, "othering", hate, fear, suspicion, and lust for power) represent. Such an awakening or enlightenment could come to any person at any time, Spencer believed; moreover, after this "last judgment", all would be "acquitted" without punishment: "[a]ll things are redeemable in my opinion and I paint them in their redeemed state" (Robinson, ${ }^{16}$ p 89). Spencer's most ambitious goal was the representation in his art—and hence the emotional/spiritual accomplishment—of human salvation.

Firstly, in the Resurrections, is found a redeeming of Spencer's own life. His various "loves and longings" are "made whole", with the day to day viewpoint of his life being seen askance sub specie aeternatis. Spencer draws together the various strands of his life, religious and secular, his associations with people and places, and his memories of their "beloved ways and habits". In particular, there is a reunion between Spencer and the important women in his life: his wives Hilda and Patricia, and close friends Daphne and Charlotte. A personal reconciliation with his first love (and continued closest friend) Hilda figures repeatedly. Even though they were physically separated (by divorce and illness) for twenty years before her death, and for nine more years before his, Spencer continued "conversing" with her in words and paint, and maintained a myth of their communication. An ultimate reconciliation between them was an act of faith for him. In his Resurrections Spencer envisaged a general harmonising of relations between people, as well as a harmonising of his own life. Families and lovers, the quick and the dead, are reunited to engage in the heaven on earth of simple social and domestic activities, leisure, and lovemaking. The resurrection is an occasion of surprise and wonderment. People are inspired by the new meaning in their life; there is a "beautiful wholeness" as the fulfilment of all life's hopes and wishes comes about. People feel and share joy at meeting again, and at the peace that this brings. It is a time of love's triumph over discord and adversity, and of sublime truth; here is a realisation that, in love, people are in heaven. 
What, then, may be said of the overall relationship between Spencer's artistry-his consciousness of his creative vision-and the way he lived his life, the control he was able to exert over it? Certainly, he was happiest when a coming together of life and vision was managed without personal suffering; but this was not always or easily the case. He suffered in the war, and through the regimentation of the army; he suffered the loss of Hilda and rejection by Patricia, and two stressful divorce proceedings; he suffered from the censorial atmosphere of a parochial England, which left him frustrated from having to hide a frank depiction of self exposure and sexual fantasy; he suffered from the dispersal of his art, a dependence on patronage, and an inability to secure any for his grander projects, and he was also short of money. And yet, it seems that such was the strength of Spencer's personal vision that he was able to reconcile life and artistry despite these sufferings and thus to sustain his life project. Hell, Spencer once suggested, must be existing in a state of unimaginativeness, and imperviousness to the spiritual. Surrounded by the imaginary world of his art and writings, this was something he never suffered; he lived his art and was pleased to do so.

Perhaps this is easiest to see in his relationship with Hilda. Hilda was probably the person to whom he felt closest in the world; in her he saw the same mental attitude to things as himself. Hilda became his great "hand holder" and affirmer, the one who secured him and grounded him so that his imagination and emotion were stimulated. Indeed, his whole philosophy of love grew out of his love for Hilda and at one point Spencer felt that his written autobiography called for contributions from Hilda too: a hodge podge showing "both our journeys".

However, Spencer's self intense nature made him turn their everyday relationship into something spiritual. His love for Hilda was as much sublime as earthly, and became more so. "Hilda was the love I felt for what I looked at", he wrote, "she was the smoke coming from the factory chimneys. I want and need her in all my experience" (Pople, ${ }^{13} \mathrm{p} 453$ ). His love united him not only to her, but to all creation and to God too; it bound all together for Spencer, affirming his existence and art. It grew so that it was impossible for him to separate Hilda from his vision, her presence in it seeming ancient and primordial. Increasingly, however, in spite of this, Spencer found himself and Hilda to be incompatible partners. Their preferred lifestyles drew them apart and their actual worlds were private ones; each could only approach the other from their respective lives. Indeed, it is arguable that Spencer found he could live with Hilda happily (and love her memory) only after divorcing her:

\section{Hilda: "You are too much of an artist to have satisfactory relations with any women. That is the price you have to pay for your genius" (Collis, ${ }^{2} \mathrm{p}$ 174). \\ Spencer: "In spite of all I feel for you and my need for you, somewhere in me is an absence of love. I never have fulfilled love for another" (Collis, ${ }^{2}$ p 195).}

Hilda becomes his phantasm and her image is more lovable than her person. "[It is] incredible", Spencer concludes, "that you exist in the flesh!" 2

There was also the Patricia question. Spencer at one stage wanted them both; Hilda: spiritual, domestic, thoughtful, considerate, sincere, complex, gauche, circumspect, intense; and Patricia: sophisticated, sexy, socially connected, elegant, stylish, vivid, lively, direct, forceful, superficial, teasing, and opportunistic. The laws of England may not allow him two wives, but he would have two all the same; he would behave as he felt proper, irrespective of how others did. Certainly, he remonstrated, marriage was a private matter whatever the law said. For Hilda and Patricia each gave him something necessary but different for the development of his artistic vision. He could be passionate, sincere, and wholehearted to both: but Hilda retreated, and then Patricia did too. Which left Spencer and Hilda continually writing and reading letters to one another to mediate their loss (exchanging letters had been their favoured form of communication and lovemaking from the start). As Hilda withdrew from his everyday life, Spencer found himself progressively able to idealise the figure Hilda represented for him. Her awkward personality could be made increasingly to conform to his artistic needs and to a position in his paintings' imagery; she joined the pantheon of personalities, real and imagined, contemporary and biblical, with which he was to populate the private world of his paintings. She is to be found there playing the role of youthful confidante, or comforting mother figure looming over a wondering Spencer like a form of protective covering. Having "lost" the real Hilda through divorce and then death, Spencer developed their spiritual union to the point where she acts as his supportive ideal companion, Madonna, and alter ego. Their erstwhile dialogue (always, perhaps, a matter more of contemporaneous monologues than of conversational give and take) $)^{2}$ is now a self dialogue which Spencer maintains within himself.

It might be argued that in constructing lovers (and others) largely in terms of his own imagination, Spencer's artistry served him primarily as a means of finding refuge from his personal difficulties; that the imaginary world of his art grew as his life's frustrations did, a means of vicarious living, justifying his actions and fulfilling his dreams. Support for this view could be drawn from Spencer's own words: "[M]y desire to paint is caused by my being unable-or being incapable—of fulfilling my desires in life itself" (Robinson, ${ }^{16}$ $\mathrm{p}$ 68). Furthermore, some of Spencer's most poignant representations of domestic perfection-recreating his own marital harmony of the 1920s-were painted while attempting to divorce Hilda in the later 1930s. Does this not show that his artistic vision rose as his real life relationships plummeted? Yet, this is not the conclusion I would draw: Spencer's artistry was not as strategic or mannered as this, his art did not compensate for his life, it was the fulfilment of his life project. One's individual self, one's real spiritual self, Spencer was fond of claiming, is present everywhere. One way he explained this was by saying that it was because one was part of God, and wherever God was you were too. Another way was by saying that he, Spencer, was desirous to absorb everything in the world into himself, to find himself to be a "treasure island", and that this was something of which all individuals were always capable. His creative impulse, Spencer continued, was all embracing: he possessed a voracious enjoyment in looking at the world, dreaming it, and recreating it. However much he dallied with the trope of being in need of mothering, he was au fond self reliant, and gained a fierce, wild, self sufficient happiness from painting alone. In the "impregnable castle of his imagination", Spencer had all that was necessary to him; nothing he really needed could be either taken from him or given to him. He wished for people to be there when he wanted to unburden himself but then for him to be left alone in order to "live my inner self". Moreover, his vision, his self, his appetite, he believed was unique to him and self created: "I know of nothing that I have ever done that I could say I did as a result of the love of God or because authorised by Him". ${ }^{2}$ This was why he was so chary of any suggestion of influences on his work: his creation was pure, his work individual. His ambition too was great. He was aware that the "almost frightening candour" with which he revealed his originally perceived world "without reserve" ${ }^{\prime 18}$ was creating a personal 
iconography that challenged every contemporary English aesthetic norm, and he once admitted he was in danger of becoming "smug on success".

\section{CONCLUSION}

Stanley Spencer wanted nothing less than to represent and realise a spiritual redemption of the entire everyday world. Looking round him, in Cookham and beyond, Spencer saw people, material objects, and practices possessed of "the sacred", of something transcendent. More than anything else this quickened his sensibilities, and he desired to portray itpictorially and verbally. Spencer felt that through this portrayal he could make this presence something really known; through his art he could present a paradisiacal reality where people shared a happy and homely brotherhood with one another and their environment, and were aware of their grace. Moreover, for Spencer, to compose this portrayal was for him to become part of it: to live too in sacred, mysterious identification with the world "in the land of me". His art was actually, personally life creating. In painting he achieved union through the space of his canvas. And in this union, everything phenomenal might be overcome, rescued, and redeemed: everything past and present, everything agreeable, disagreeable and mortifying, misfortuned, friendly, and tragic.

It was not by chance that Stanley often pictured himself and his characters walking with Christ, and described himself as part of God. Stanley was a Christ like prophet to himself: "[p]ainting with me was the crowning of an already elected king"13; "[I am] a new kind of Adam, and joy is the means by which I name things". ${ }^{2}$ In transposing his friends and lovers and himself, Cookham, Port Glasgow, Leonard Stanley, Hampstead, and so on, into the imagined worlds of his figurative art, he was able to displace, represent, and replace the whole world in a quasidivine way. His message of love-ambitious, arrogant, certain, strange-might sit uneasily alongside English politeness and reserve but one day it would be acclaimed the truth. Meantime, his metaphysic was a source of wellbeing and something with which his "nonartistic projects", such as these were, had to come to terms:

Stanley: "[i]t has been my way to make things as far as I am able to-fit me" (Arts Council, ${ }^{19}$ p 21).
Hilda: "You would reckon to shape your own destiny, and therefore forcing things and riding right over them is part of your outlook. To you that seems right, to take the matter in your own hands and shape it as you will" (Pople, ${ }^{13}$ p 368).

It would be my conclusion that weighing up the evidence of his life this was something which Stanley Spencer succeeded in effecting. The power of his imagination and the discipline with which he lived it made Stanley his own man. His artistic vision amounted to a life project whereby he acquired the genius to inhabit successfully a world of his own construal. He related to a social environment created in his own image.

\section{ACKNOWLEDGEMENTS}

The final drafting of this paper took place while I was a Visiting Professor at the School of Anthropology, Geography, and Environmental Studies, University of Melbourne. I am very grateful to members of that institution, in particular Professor Andrew Dawson. I am also grateful to the editors of this special issue and the anonymous reviewers for their constructive commentaries.

\section{REFERENCES}

1 Rapport NJ. Transcendent individual: towards a liberal and literary anthropology. London: Routledge, 1997.

2 Collis M. Stanley Spencer. London: Harvill, 1962.

3 Emerson RW. The portable Emerson. Harmondsworth: Penguin, 1981:152.

4 Kateb G. Introduction: exile, alienation and estrangement. Soc Res 1991;58:135-8.

5 Rapport NJ, Dawson A, eds. Home and movement: a polemic. Migrants of identity: perceptions of home in a world of movement. Oxford: Berg, 1998.

6 Cohen AP. Self consciousness. London: Routledge, 1994:136.

7 Schuetz A. The phenomenology of the social world. London: Heinemann, 1972.

8 Jackson $\mathrm{M}$. Introduction: phenomenology, radical empiricism, and "anthropological critique". Things as they are. Bloomington, IN: Indiana University Press, 1996:22.

9 Eves R. The magical body. Amsterdam: Harwood Academic, 1998:20-1.

10 Sartre J-P. The psychology of imagination. New York: Citadel, 1972.

11 Rapport NJ. I am dynamite: an alternative anthropology of power. London: Routledge, 2003.

12 Nietzsche F. Human. All too human. Harmondsworth: Penguin, 1994.

13 Pople K. Stanley Spencer. London: Collins, 1991.

14 Bell K. Stanley Spencer. London: Phaidon, 1992:232.

15 Glew A, ed. Stanley Spencer: letters and writing. London: Tate, 2001.

16 Robinson D. Stanley Spencer. London: Phaidon, 1994.

17 Spencer S. The apotheosis of love. London: Barbican Art Gallery, 1991.

18 Rothenstein E. Stanley Spencer. London: Phaidon, 1945.

19 Arts Council of Great Britain. Stanley Spencer. Glasgow: Maclehose, 1976. 